\title{
OPTIMIZATION OF KERATINASE PRODUCTION BY ACTINOMYCES FRADIAE 119 AND ITS APPLICATION IN DEGRADATION OF KERATIN CONTAINING WASTES
}

\author{
V. Matikevičienè ${ }^{1}$, S. Grigiškis ${ }^{1}$, D. Levišauskas ${ }^{2}$, K. Sirvydytè ${ }^{1}$, \\ O. Dižavičiené ${ }^{1}$, D. Masiliūniené ${ }^{1}$, O. Ančenko ${ }^{1}$ \\ 1- JSC „Biocentras”, V. Graičiūno st. 10, LT-02241 Vilnius, Lithuania \\ Ph.: +37052661313, fax: +37052602454, email: biocentras@ biocentras.lt \\ 2- Process Control Department, Kaunas University of Technology \\ Studentų st. 50, LT-51368 Kaunas, Lithuania
}

\begin{abstract}
The aim of this study was to identify and optimize significant technological parameters influencing keratinolytic enzyme production by A. fradiae 119 and to study its ability to degrade keratin. In the present work chicken feathers meal (CFM) was found to be an excellent substrate for keratinase induction by $A$. fradiae 119. The strain produced $164 \mathrm{KU} / \mathrm{mL}$ keratinolytic activity in basal medium containing $7.5 \mathrm{~g} / \mathrm{L} C F M$ as the sole source of carbon and nitrogen. Increased keratinolytic activity was achieved in media with ammonium sulfate as nitrogen source, the application of additional nitrogen sources to media containing CFM slightly decreased keratinase synthesis. Optimal parameters of the cultivation process were determined: $p H$ of cultivation medium - 7.2, temperature $-34{ }^{\circ} \mathrm{C}$ and inoculum's size $-8 \%$, using the response surface methodology. The yield of keratinase activity was increased by $46 \%$ (267 KU/mL) after optimization of the cultivation process. The good ability of cultural liquid to degrade feathers and wool was detected.
\end{abstract} methodology.

Keywords: Actinomyces fradiae, keratin degradation, keratinase, optimization, response surface

\section{Introduction}

Keratin is a fibrous and insoluble structural protein extensively cross-linked with disulphide, hydrogen and hydrophobic bonds, resulting in mechanical stability and resistance to common proteolytic enzyme such as pepsin, trypsin and papain [1]. Keratins represent the major constituents of skin and its appendages such as nails, hair, feathers, and wool.

The leather and fur plants throw away considerable amounts of materials containing keratin. Until recent years, these materials along with other animal wastes were treated at high temperatures and milled in order to produce the so called ,,animal flour” and used as ,protein supplement" into the feed mixtures of domestic animals. However, it was established that this flour is the carrier of the enigmatic cause of some related diseases, for example mad cow, swine fever and etc. Utilizing poultry feathers as a fermentation substrate in conjunction with keratin-degrading microorganisms or enzymatic biodegradation may a better alternative to reduce environmental waste [2].

A group of proteolytic enzymes which are able to hydrolyze insoluble keratins more efficiently than other proteases are called keratinases, produced by some microorganisms [3]. The growth and enzyme production by microorganisms are strongly influenced by medium composition, thus optimization of media components and cultural parameters is the primary task in biological process [4].

The aim of this study was to identify and optimize significant technological parameters influencing keratinolytic enzyme production by A. fradiae 119 and to study its ability to degrade keratin. 


\section{Materials and methods}

Actinomys fradiae 119 strain, obtained from JSC „Biocentras” microorganism culture collection, was used for the investigations. Keratinase production was investigated in basal medium composed of $(\mathrm{g} / \mathrm{L})$ : carbon source $-7.5 \mathrm{~g} / \mathrm{L}$, nitrogen source $\left(\mathrm{NH}_{4} \mathrm{Cl}\right)-1 \mathrm{~g} / \mathrm{L}$, $\mathrm{KH}_{2} \mathrm{PO}_{4}-0.45, \mathrm{MgSO}_{4} \cdot 7 \mathrm{H}_{2} \mathrm{O}-0.90, \mathrm{ZnSO}_{4} \cdot 7 \mathrm{H}_{2} \mathrm{O}-0.20, \mathrm{FeSO}_{4}-0.01, \mathrm{MnSO}_{4} \cdot 5 \mathrm{H}_{2} \mathrm{O}-$ $0.01, \mathrm{CaCO}_{3}-4.0, \mathrm{pH} 7.4$. The medium was autoclaved at $121^{\circ} \mathrm{C}$ for $30 \mathrm{~min}$.

To optimize the composition of the medium, various carbon sources (including chicken feathers, chicken feathers meal, wool, casein, glucose, starch); as well as organic (yeast extract and gelatine) and inorganic $\left(\mathrm{NH}_{4} \mathrm{Cl} ;\left(\mathrm{NH}_{4}\right)_{2} \mathrm{SO}_{4}\right)$ nitrogen sources were individually evaluated for their performance in keratinolytic enzyme production.

The keratinolytic enzyme was produced in a $500 \mathrm{~mL}$ Erlenmeyer flask containing $100 \mathrm{~mL}$ culture medium maintained for $24 \mathrm{~h}$ at $30{ }^{\circ} \mathrm{C}$ and $200 \mathrm{rev} / \mathrm{min}$. The medium was inoculated with $5 \%$ of $20 \mathrm{~h}$ preculture suspension.

Keratinolytic activity was detected using azokeratin as substrate. Azokeratin was prepared by reacting ball-milled feathers with sulfanilic acid and $\mathrm{NaNO}_{2}$ by use of a method described by Shih and Williams [5]. For a standard assay, $9.6 \mathrm{mg}$ of azokeratin was added to a centrifuge tube along with $1.92 \mathrm{~mL}$ of $50 \mathrm{mM}$ Tris- $\mathrm{HCl}$ buffer ( $\mathrm{pH} 7.5)$. This mixture was agitated until azokeratin was completely suspended. $0.48 \mathrm{~mL}$ aliquot enzyme solution was mixed with azokeratin, and then was incubated for $1 \mathrm{~h}$ in a $45{ }^{\circ} \mathrm{C}$ thermoshaker. The reaction was terminated by the addition of $1.6 \mathrm{~mL}$ of $25 \%$ trichloroacetic acid, and the mixture was filtered. $\mathrm{A}_{450}$ of the filtrate was measured with a UV-1601 spectrophotometer. Control was prepared by adding tricholacetic acid to reaction mixture before adding the enzyme solution. One unit (U) of keratinase activity, under the given conditions, was defined as the amount of enzyme causing 0.01 increases in absorbance between sample and control at $450 \mathrm{~nm}$ after $1 \mathrm{~h}$. The result was taken as an average of three replicates.

Caseinolytic activity was determined by modified Anson method [6]. Tirosine was used as a standard.

Optimal parameters of cultivation process, namely $\mathrm{pH}$, temperature and inoculum's size, were studied by response surface methodology (RSM). The experimental optimization procedure consisted of four steps:

1. Selection of preliminary values of cultivation process parameters using a priori knowledge about the culture under optimization.

2. Design and realization of statistical experiment in the selected area of technological parameters values variations around the predetermined point.

3. Identification of statistical model for the response surface estimation. A second order polynomal, which includes all interaction terms, is used to calculate the predicted response:

$$
Y=a_{0}+\sum_{i=1}^{n} a_{i} x_{i}+\sum_{i=1}^{n} a_{i i} x_{i}^{2}+\sum_{i=1}^{n} \sum_{j=i+1}^{n} a_{i j} x_{i} x_{j}
$$

where $Y$ - predicted response (maximal ceratinolytic activity); $x_{i}$-independent variables (parameters of cultivation process); $\mathrm{n}$ - number of independent variables. Parameters of the polynomal model (1) are identified using the least-squares method.

4. Model-based prediction of cultivation process point parameters, at which the maximum keratinolytic activity is obtained, and investigation of the calculated point location. If the point is on the boundary of experimental design area, a normalized gradient vector at this point is calculated:

$$
\operatorname{grad}_{n} Y \mathbf{x}_{-}=\frac{\nabla Y(\mathbf{x})}{\|\nabla Y(\mathbf{x})\|_{\mid \mathbf{x}=\mathbf{x}_{\max }}}
$$


Matikevičienė V., Grigiškis S., Sirvydytė K., Levišauskas D., Dižavičienė O., Masiliūnienė D., Ančenko O. OPTIMIZATION OF KERATINASE PRODUCTION BY ACTINOMYCES FRADIAE 119 AND ITS APPLICATION IN DEGRADATION OF KERATIN CONTAINING WASTES

The gradient vector (2) determines the search direction of the optimum parameters of cultivation process point outside the experimental design area. Along the calculated direction the expected optimum point is chosen and procedure returns to the step 2 . If the point is inside the experimental design area, the point is assumed to be an optimum and the test experiment is carried out at that point [7].

Disintegration of whole chicken feathers was estimated by incubation with the cultural liquid for $24 \mathrm{~h}$ in $100 \mathrm{~mL}$ Tris- $\mathrm{HCl}, \mathrm{pH} 7.5$ buffer at $45^{\circ} \mathrm{C}$. Degradation of wool keratin was observed for 9 days under the same conditions.

\section{Results and discussion}

Each microorganism has its own special conditions for the maximum enzyme production. Keratinase production was first tested in medium containing different carbon sources $(5 \mathrm{~g} / \mathrm{L})$. The obtained results are presented in Table 1. The A. fradiae 119 exhibited highest productivity of keratinase in the culture media that contained chicken feathers meal (CFM) as the carbon source $(167.0 \mathrm{KU} / \mathrm{mL})$, followed by chicken feathers $(158.5 \mathrm{KU} / \mathrm{mL})$, casein $(128.5 \mathrm{KU} / \mathrm{mL})$ and wool $(128.0 \mathrm{KU} / \mathrm{mL})$. Glucose and starch carbon sources resulted in a weak enzyme production level, but did not repress the synthesis of keratinase production. This is in contrary to the most of the reports on keratinase and protease production where starch and glucose inhibited enzyme production [3,8]. The highest caseinolytic activity levels were obtained with CFM $(0.60 \mathrm{CU} / \mathrm{mL})$ followed by raw chicken feathers $(0.47 \mathrm{CU} / \mathrm{mL})$. Caseinase production by $A$. fradiae 119 was repressed when the strain was grown in the presence of wool, casein, glucose, or starch as carbon sources. Chicken feathers meal was selected as the best carbon source for keratinase and caseinase production by A. fradiae 119 .

Table 1 .

Effect of different carbon sources on keratinase and caseinase production by

A. fradiae 119

\begin{tabular}{|l|c|c|}
\hline \multicolumn{1}{|c|}{ Carbon source } & $\begin{array}{c}\text { Keratinolytic } \\
\text { activity, KU/mL }\end{array}$ & $\begin{array}{c}\text { Caseinolytic } \\
\text { activity, CU/mL }\end{array}$ \\
\hline Chicken feathers meal & 167.0 & 0.60 \\
\hline Chicken feathers & 158.5 & 0.47 \\
\hline Wool & 128.0 & 0.04 \\
\hline Casein & 128.5 & 0.07 \\
\hline Glucose & 78.0 & 0.04 \\
\hline Starch & 95.0 & 0.05 \\
\hline
\end{tabular}

The effect of CFM concentration on keratinase production was investigated. As shown in Fig. 1., keratinase activity reached a maximum value $(163.8 \mathrm{KU} / \mathrm{mL})$ at concentration of 7.0 $\mathrm{g} / \mathrm{L}$. Further addition of CFM decreased the level of enzyme.

The effect of various additional nitrogen sources on keratinase and caseinase production, in media containing $7.0 \mathrm{~g} / \mathrm{L}$ of chicken feathers meal as a carbon source, was also carried out. The obtained results are presented in Table 2. Keratinase and caseinase production was improved by adding $\left(\mathrm{NH}_{4}\right)_{2} \mathrm{SO}_{4}$ to the medium containing CFM (control). The other nitrogen sources (yeast extract, gelatin, peptone, $\mathrm{NH}_{4} \mathrm{Cl}$ ) did not enhance keratinases and caseinases production and supported similar or lower levels compared to the medium containing only CFM as a carbon and nitrogen source. Fakhfakh-Zouari et al. (2010) estimated, that the 
Matikevičienė V., Grigiškis S., Sirvydytė K., Levišauskas D., Dižavičienė O., Masiliūnienė D., Ančenko O. OPTIMIZATION OF KERATINASE PRODUCTION BY ACTINOMYCES FRADIAE 119 AND ITS APPLICATION IN DEGRADATION OF KERATIN CONTAINING WASTES

addition of ammonium chloride and ammonium sulfate to media containing chicken feathers meal as a carbon source slightly decreased protease synthesis [4].

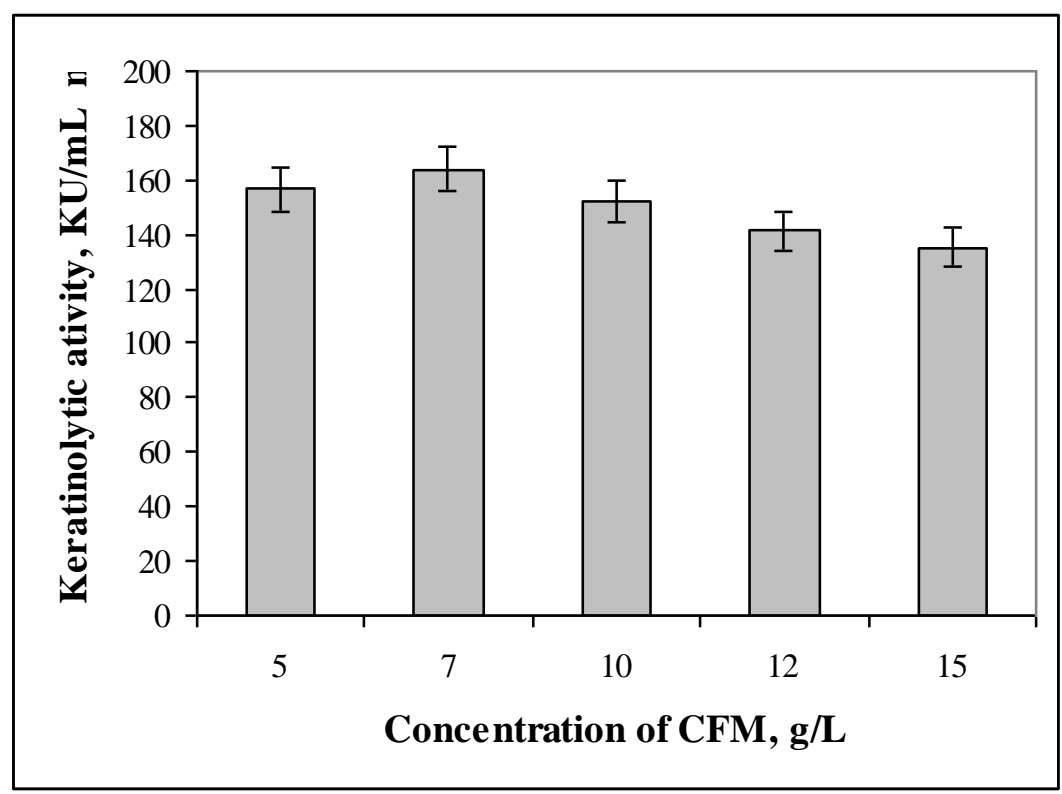

Fig. 1 Effect of chicken feathers meal concentration on keratinase production by A. fradiae 119

Whereas, the ability of the strain to grow in media containing chicken feathers meal as organic substrate indicated that it can obtain its carbon and nitrogen directly from this substrate. This is in line with previous scientific findings $[3,4,8]$.

Table 2.

\section{Effect of different additional nitrogen sources on keratinase and caseinase production}

by $A$. fradiae 119

\begin{tabular}{|l|c|c|}
\hline \multicolumn{1}{|c|}{ Nitrogen source } & $\begin{array}{c}\text { Keratinolytic } \\
\text { activity, KU/mL }\end{array}$ & $\begin{array}{c}\text { Caseinolytic } \\
\text { activity, CU/mL }\end{array}$ \\
\hline Control & 162.0 & 0.47 \\
\hline Yeast extract & 136.5 & 0.24 \\
\hline Gelatin & 132.0 & 0.43 \\
\hline $\mathrm{NH}_{4} \mathrm{Cl}$ & 151.0 & 0.22 \\
\hline$\left(\mathrm{NH}_{4}\right)_{2} \mathrm{SO}_{4}$ & 169.8 & 0.51 \\
\hline Peptone & 124.5 & 0.43 \\
\hline
\end{tabular}

Keratinase secretion by microorganisms is substantially influenced not only by carbon and nitrogen sources, but also by main technological parameters of cultivation process. Optimization of cultivation process parameters is the primary task in biological process. The goal of optimization procedure was to evaluate optimal technological parameters of cultivation process in order to maximize the yield of keratinolytic enzyme at the end of bath cultivation processes. The parallel experiments were realized using the $B_{3}$ experimental plan, which contains 15 experimental points. Experiments were repeated two times to evaluate the reproducibility of experimental results. The main factors that were considered to influence the 
Matikevičienė V., Grigiškis S., Sirvydytė K., Levišauskas D., Dižavičienė O., Masiliūnienė D., Ančenko O. OPTIMIZATION OF KERATINASE PRODUCTION BY ACTINOMYCES FRADIAE 119 AND ITS APPLICATION IN DEGRADATION OF KERATIN CONTAINING WASTES

cultivation process efficiency are: cultivation temperature, initial medium $\mathrm{pH}$ and inoculum's size. Two series of factorial experiments were performed. In the first experiment, technological parameters were changed within the range: temperature $\left(x_{1}\right)-25 \div 40{ }^{0} \mathrm{C} ; \mathrm{pH}$ $\left(x_{2}\right)-6.5 \div 8.5$; inoculum's size $\left(x_{3}\right)-2 \div 10 \%$.

Analysis of obtained results demonstrated that the point, at which maximum keratinolytic activity is predicted, lies on boundary of experimental design area. At this point the gradient vector was calculated and expected direction of optimal point was determined (data not shown). Experimental design of matrices together with experimental results of $2^{\text {nd }}$ experiment is presented in Table 3.

Table 3.

Experimental design matrices with code $\left(x_{i}\right)$ and real $\left(X_{i}\right)$ variables for Actinomyces fradiae 119 cultivation process and the keratinolytic activity $\left(Y_{\text {exp }}\right)$ as dependent variable

\begin{tabular}{|c|c|c|c|c|c|c|c|c|}
\hline \multirow{2}{*}{ Nr. } & \multicolumn{3}{|c|}{ Code values } & \multicolumn{3}{c|}{ Real values } & \multicolumn{2}{c|}{$Y_{\text {exp }}, \mathrm{KU} / \mathrm{mL}$} \\
\cline { 2 - 9 } & $x_{1}$ & $x_{2}$ & $x_{3}$ & $X_{1}$ & $X_{2}$ & $X_{3}$ & 1 & 2 \\
\hline 1 & +1 & +1 & +1 & 38 & 7,5 & 8 & 159.3 & 144.0 \\
\hline 2 & -1 & +1 & +1 & 30 & 7.5 & 8 & 173.3 & 173.3 \\
\hline 3 & +1 & -1 & +1 & 38 & 6.5 & 8 & 120.0 & 118.7 \\
\hline 4 & -1 & -1 & +1 & 30 & 6.5 & 8 & 128.0 & 129.3 \\
\hline 5 & +1 & +1 & -1 & 38 & 7.5 & 4 & 125.3 & 121.3 \\
\hline 6 & -1 & +1 & -1 & 30 & 7.5 & 4 & 144.0 & 140.7 \\
\hline 7 & +1 & -1 & -1 & 38 & 6.5 & 4 & 130.7 & 126.0 \\
\hline 8 & -1 & -1 & -1 & 30 & 6.5 & 4 & 95.3 & 96.7 \\
\hline 9 & +1 & 0 & 0 & 38 & 7.0 & 6 & 133.3 & 138.0 \\
\hline 10 & -1 & 0 & 0 & 30 & 7.0 & 6 & 141.3 & 149.0 \\
\hline 11 & 0 & +1 & 0 & 34 & 7.5 & 6 & 131.3 & 134.0 \\
\hline 12 & 0 & -1 & 0 & 34 & 6.5 & 6 & 98.0 & 101.3 \\
\hline 13 & 0 & 0 & +1 & 34 & 7.0 & 8 & 156.0 & 158.3 \\
\hline 14 & 0 & 0 & -1 & 34 & 7.0 & 4 & 174.7 & 182.7 \\
\hline 15 & 0 & 0 & 0 & 34 & 7.0 & 6 & 182.7 & 188.0 \\
\hline
\end{tabular}

Experimental data were used to identify parameter values of statistical model (1), which was used to calculate the predicted responses corresponding to results of the experiment. The response surfaces are illustrated by the isoresponse contour plots (Figure 2).
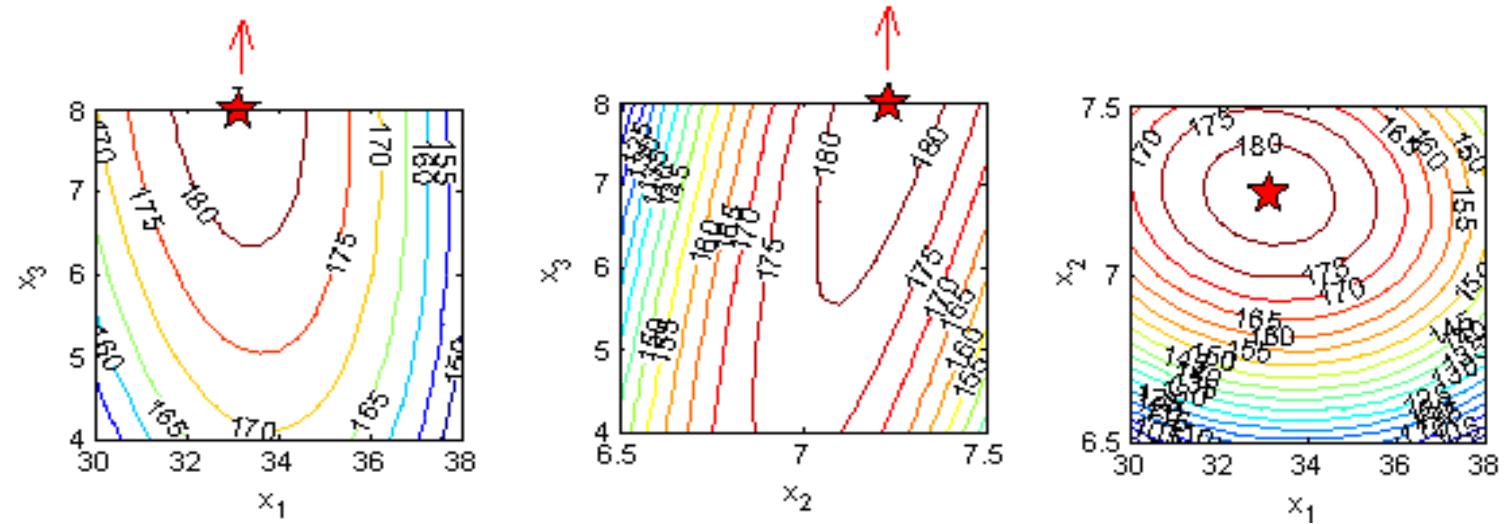

Fig. 2 Isoresponse contour plots of Actinomyces fradiae 119 keratinolytic activity 
On regression analysis of experimental data, following equation was obtained for keratinase production:

$$
\begin{aligned}
Y= & 179.54-2.807 x_{1}+13.28 x_{2}-1.395 x_{3}-21.70 x_{1}^{2}-32.18 x_{2}^{2}- \\
& -2.895 x_{3}^{2}-6.141 x_{1} x_{2}-3.704 x_{1} x_{3}+16.14 x_{2} x_{3}
\end{aligned}
$$

Optimal parameters of the cultivation process of $A$. fradiae 119 predicted by statistical model were determined: initial $\mathrm{pH}$ of cultivation medium -7.2 , temperature $-34{ }^{\circ} \mathrm{C}$ and inoculum's size $-8 \%$. The bacterium produced $183 \mathrm{KU} / \mathrm{mL}$ keratinase in $24 \mathrm{~h}$. The test experiment was carried out at that optimum point and keratinase production increased by $46 \%(267 \mathrm{KU} / \mathrm{mL})$ after optimization of the cultivation process.

Cultural liquid, grown under optimal conditions, was used to evaluate its ability to degrade native chicken feathers and wool. The degradation of feathers started at $4 \mathrm{~h}$ and the degradation of barbules was observed. Full disintegration of feather barbules and rachis was detected after $24 \mathrm{~h}$ of the treatment. However, earlier studies have reported longer incubation periods of $48 \mathrm{~h}$ to 28 days $[9,10]$.

Degradation of wool was assessed using electron microscopy (Fig.3). Actinomyces fradiae 119 formed the branched networks of hyphae on the wool fiber surface after one day of treatment. After 9 days of incubation, the great majority of wool fibres showed complete disintegration and appeared as separate, irregular fragments. This indicates that wool fibre structure had been altered by the activities of A. fradiae 119 .

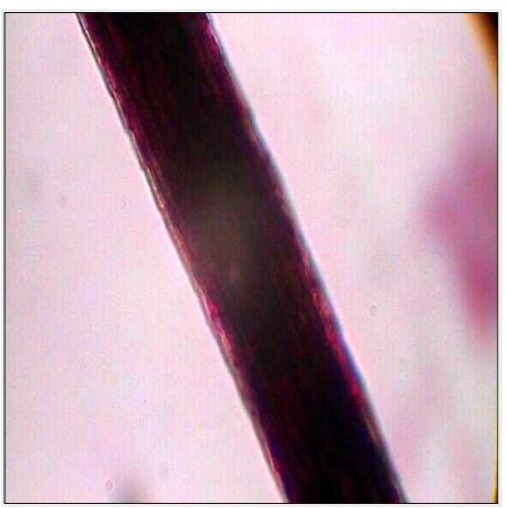

a)

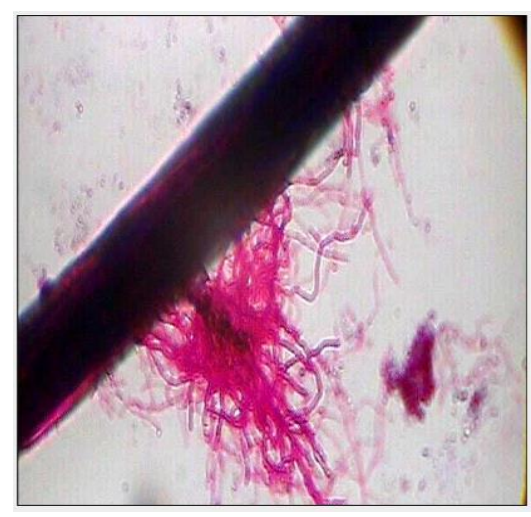

b)

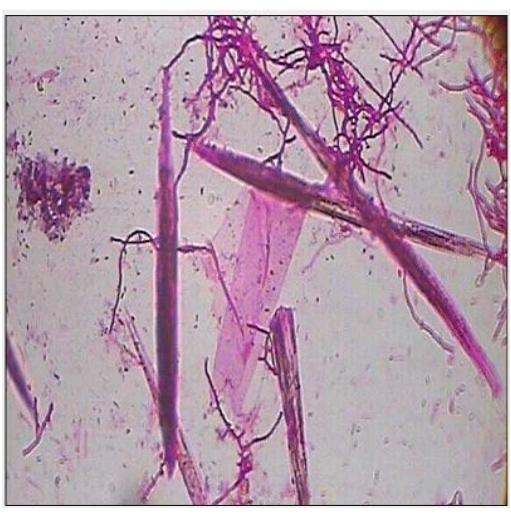

c)

Fig. 3 Hydrolization of wool fibers by A. fradiae 119:

a) unhydrolized wool fiber; b) after 1 day treatment; c) after 9 days treatment

Solubilization of native feathers and wool fibers by the cultural liquid showed the biotechnological potential involving keratin hydrolysis in the processing of keratin containing wastes.

\section{Conclusions}

Chicken feathers meal was found to be an excellent substrate for keratinase production by A. fradiae 119. The strain produced $164 \mathrm{KU} / \mathrm{mL}$ keratinolytic activity in basal medium containing $7.5 \mathrm{~g} / \mathrm{L} \mathrm{CFM}$ as a sole source of carbon and nitrogen.

Organic nitrogen sources were used efficiently for keratinase production. Increased keratinolytic activity was achieved in media with ammonium sulfate as additional nitrogen source, whereas the addition of other nitrogen sources to media containing chicken feathers meal slightly decreased keratinase synthesis.

Optimal parameters of the cultivation process were determined: initial $\mathrm{pH}$ of cultivation medium -7.2 , temperature $-34{ }^{\circ} \mathrm{C}$ and inoculum's size $-8 \%$, using the response surface 
Matikevičienė V., Grigiškis S., Sirvydytė K., Levišauskas D., Dižavičienė O., Masiliūnienė D., Ančenko O. OPTIMIZATION OF KERATINASE PRODUCTION BY ACTINOMYCES FRADIAE 119 AND ITS APPLICATION IN DEGRADATION OF KERATIN CONTAINING WASTES

methodology. The bacterium produced $183 \mathrm{KU} / \mathrm{mL}$ keratinase in $24 \mathrm{~h}$ which was increased by $46 \%(267 \mathrm{KU} / \mathrm{mL})$ after optimization of the cultivation process.

The good ability of cultural liquid to degrade feathers and wool was detected.

\section{References}

1. Radha, S., Gunasekaran, P. Cloning and expression of keratinase gene in Bacillus megaterium and optimization of fermentation conditions for the production of keratinase by recombinant strain. Journal of Applied Microbiology, 103. 2007, p. 1301-1310.

2. Matikevičienė, V., Masiliūnienè, D., Grigiškis, S. Degradation of keratin containing wastes by bacteria with keratinolytic activity. Proceedings of the $7^{\text {th }}$ international scientific and practical conference "Environment. Technology. Resources", June 25-27, 2009. Rezekne. 2009, p. 284-289. ${ }^{1}$ Shih, J. C. H.; Williams, C. M. 1992. Purified Bacillus licheniformis PWD-1 keratinase. United States Patent. Nr. 5171682. $14 \mathrm{p}$.

3. Hossain, M.S., Azad, A.K., Abu Sayem, S.M., Mostafa, G., Hoq, M.M. Production and partial characterization of feather-degrading keratinolytic serine protease from Bacillus licheniformis MZK-3. Journal of Biological Sciences, 7-4. 2007, p. 599-606.

4. Fakhfakh-Zouari, N., Haddar, A., Hmidet, N., Frikha, F., Nasri, M. Application of statistical experimental design for optimization of keratinases production by Bacillus pumilus A1 grown on chicken feather and some biochemical properties. Process Biochemistry, 45. 2010, p. 617-626.

5. Shih, J. C. H.; Williams, C. M. Purified Bacillus licheniformis PWD-1 keratinase. United States Patent. Nr. 5171682. 1992, p. 14.

6. Lanoë, J.; Dunnigan, J. Improvements of the Anson assay for measuring proteolytic activities in acidic $\mathrm{pH}$ range, Analytical Biochemistry, 89-2. 2004, p. 461-471.

7. Levišauskas, D., Tekorius, T., Čipinyte, V., Grigiškis, S. Experimental optimization of nutrient media for cultivation of Arthrobacter bacteria. Latvijas Kīmijas Žurnāls, 1. 2004, p. 75-80.

8. Fakhfakh, N., Kanoun, S., Manni, L., Nasri,M. Production and biochemical and molecular characterization of a keratinolytic serine protease from chicken feather-degrading Bacillus lichiniformis RPk. Canadian Journal of Microbiology, 55. 2009, p. 427-436.

9. Ignatova, Z., Gousterova, A., Spassov, G., and Nedkov, P. Isolation and partial characterization of extracellular keratinase from a wool degrading thermophilic actinomycete strain Thermoactinomyces candidus. Canadian Journal of Microbiology, 45. 1999, p. 217-222.

10. Nam, G.W., Lee, D.W., Lee, H.S., Lee, N.J., Kim, B.C., Choe, E.A., Hwang, J.K., Suhartono, M.T., and Pyun, Y.R. Native feather degradation by Fervidobacterium islandicum AW-1, a newly isolated keratinase producing thermophilic anaerobe. Archives of Microbiology, 178. 2002, p. 538-547. 